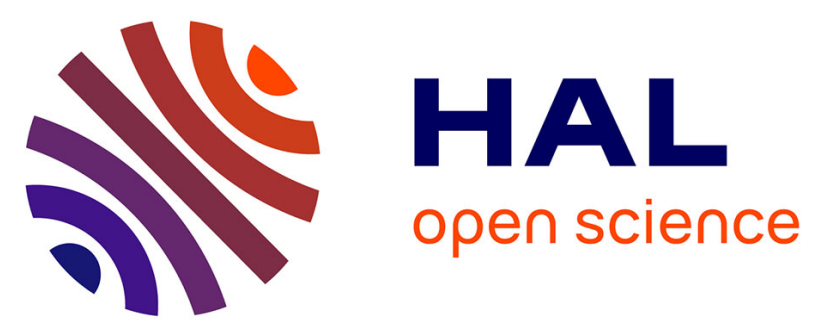

\title{
Erosion of insect diversity in response to 7000 years of relative sea-level rise on a small Mediterranean island
}

Yoann Poher, Philippe Ponel, Frédéric Guiter, Valérie Andrieu-Ponel, Frederic Medail

\section{- To cite this version:}

Yoann Poher, Philippe Ponel, Frédéric Guiter, Valérie Andrieu-Ponel, Frederic Medail. Erosion of insect diversity in response to 7000 years of relative sea-level rise on a small Mediterranean island. Biodiversity and Conservation, 2017, 26 (7), pp.1641-1657. 10.1007/s10531-017-1322-z . hal-01681539

\section{HAL Id: hal-01681539 \\ https://hal.science/hal-01681539}

Submitted on 26 Apr 2018

HAL is a multi-disciplinary open access archive for the deposit and dissemination of scientific research documents, whether they are published or not. The documents may come from teaching and research institutions in France or abroad, or from public or private research centers.
L'archive ouverte pluridisciplinaire HAL, est destinée au dépôt et à la diffusion de documents scientifiques de niveau recherche, publiés ou non, émanant des établissements d'enseignement et de recherche français ou étrangers, des laboratoires publics ou privés. 


\title{
Erosion of insect diversity in response to 7000 years of relative sea-level rise on a small Mediterranean island
}

\author{
Yoann Poher $^{1}$. Philippe Ponel $^{1}$. Frédéric Guiter ${ }^{1}$. \\ Valérie Andrieu-Ponel ${ }^{1}$. Frédéric Médail ${ }^{1}$
}

Received: 22 June 2016 / Revised: 25 January 2017 / Accepted: 10 February 2017

\begin{abstract}
We have investigated the potential effects of global sea-level rise on Mediterranean coastal wetlands by studying the Coleoptera and pollen fossil remains in a 7000-year sedimentary record, which we obtained from a coastal marshy area on a small Mediterranean island (Cavallo, southern Corsica). Using beetle structural diversity and plant composition as recorded prior to marine and human influences as a 'past analogue', we reconstructed the impact of the Holocene relative sea-level rise on the coastal ecosystem. Our results show that beetle species richness and diversity were highest when freshwater was predominant, which was the case until about 6200 years ago. We also found that a major increase in salinity had occurred over the last 5300 years, experiencing a peak rate of increase at about 3700 years ago. These changes are clearly reflected in the fossil records of the following key taxa: halophilous beetles (Ochthebius sp., Pterostichus cursor), halophilous plants (Chenopodiaceae, Tamarix) and non-pollen palynomorphs (microforaminiferal linings). In particular, we note that the majority (60\%) of wetland beetle fauna became locally extinct in response to the salinity changes, and these changes were exacerbated by the recent aggravation of human pressures on the island. The major part of this diversity loss occurred 3700 years ago, when the relative Mediterranean sea-level rose above $-1.5 \pm$ 0.3 meters. These findings demonstrate the value of fossil beetle assemblage analysis as a diagnostic for the response of coastal wetland biodiversity to past salinity increases, and serve as a means of forecasting the effects of sea-level rise in the future. The conservation of inland freshwater bodies could ultimately prove essential to preserving freshwater insect diversity in threatened coastal environments.
\end{abstract}

Keywords Fossil Coleoptera Biodiversity Island Sea-level rise Wetland

Communicated by Eckehard G. Brockerhoff.

Electronic supplementary material The online version of this article (doi:10.1007/s10531-017-1322-z) contains supplementary material, which is available to authorized users.

Yoann Poher

yoann.poher@imbe.fr

1 Aix Marseille Univ, Univ Avignon, CNRS, IRD, IMBE, Marseille, France 


\section{Introduction}

Coastal ecosystems such as wetlands are major biodiversity hotspots. Despite being the subject of intense research, the full extent to which these fragile environments are vulnerable to future global sea-level rise remains poorly understood. Mediterranean coastal wetlands are particularly challenging to study because they are subject to threats from human activities and land-use changes (Beltrame et al. 2012) in addition to relative sea-level rise (RSLR) induced by current climate warming. RSLR is particularly damaging because it can lead to the intensification of coastal erosion and to the submersion of low elevation islands and coastal wetlands (Nicholls et al. 2016; Wong et al. 2014).

Fortunately, there are multiple methods by which these myriad effects can be teased apart and analysed. One approach is based on predictive global sea-level change models, and has been employed in recent studies to suggest that several oceanic island hotspots will likely suffer a great loss of terrestrial biodiversity (Bellard et al. 2013a, b; Courchamp et al. 2014). Although quite informative, such prospective studies do not consider local parameters (which may differ between islands) together with the 'historical background'. For this reason they should be thought of as providing more of a general idea rather than a highly detailed view of the situation.

A more nuanced perspective can be obtained using the alternate approach, which is to begin by reconstructing the ecosystem dynamics of Mediterranean wetlands in the distant past (Anderson et al. 2006; Magurran et al. 2010; Willis et al. 2010). However, this tends to be complicated by the fact that ecological monitoring records do not typically go back more than a few decades. Therefore, palaeoecological investigations on sedimentary archives, through multi-disciplinary approach, are the key to understanding how coastal ecosystems have responded to past RSLR. This knowledge can then be used to shed light on future RSLR scenarios (Woodroffe and Murray-Wallace 2012). This approach, though potentially quite effective, appears relatively infrequently in the body of literature dealing with the impact of past RSLR on the biodiversity of coastal wetlands (Virah-Sawmy et al. 2009).

In this paper we present a multi-proxy study, using beetles, pollen, sedimentology and radiometric dating to analyse a sedimentary profile from the small Corsican island of Cavallo (Lavezzi archipelago). We chose these particular proxies and this specific record because (1), fossil beetles and pollen are excellent markers of past environmental conditions and landscape dynamics, (2) Corsica has historically been the source of several paleoecological records and has a landscape whose Holocene history is relatively well known (e.g., Reille 1984, 1992), and (3) past RSLR is well documented in this part of the Mediterranean (Laborel et al. 1994; Lambeck and Purcell 2005; Morhange et al. 2001; Vacchi et al. 2016; Vella and Provansal 2000).

The overall aim of the present study is to (1) reconstruct past ecosystem dynamics and past Coleoptera diversity changes in relation to Holocene sea-level rise, (2) provide a 'past analogue' suitable for predicting the condition of the area by 2050 (Galassi and Spada 2014), and (3) propose strategies for insect conservation within the framework of future sea-level rise in the Mediterranean basin. 


\section{Materials and methods}

\section{Study site, sampling and chronology}

Cavallo Island [N 41 $22^{\prime} 06^{\prime \prime} / \mathrm{E} 9^{\circ} 15^{\prime} 45^{\prime \prime}$; area: 120 ha; maximal elevation: 32 meters above sea level (m.a.s.l.)] is a low-elevation island of the Lavezzi archipelago (Southern Corsica, France; Fig. 1a). The waters surrounding Cavallo are shallow, with depths rarely exceeding $10 \mathrm{~m}$. A coastal retrodunal pond (Greco pond; 0.48 ha, 1 m.a.s.l.), located on the northern part of the island, was sampled using a Russian corer. A $340 \mathrm{~cm}$ length sediment profile (CAVA-1) was obtained. After description of its lithology, CAVA-1 was subsampled into seventy $5 \mathrm{~cm}$-thick slices and 38 circa $2 \mathrm{~cm}^{3}$ subsamples respectively for coleopteran and pollen analyses.

Six AMS radiocarbon measurements were performed on bulk peat sediment samples (Poznan Radiocarbon Dating Laboratory, Poland). Ages were calibrated to calendar years before present (cal. yr B.P.; present fixed at 1950) and an interpolated age-depth model was created using the 'CLAM' R package (Blaauw 2010) from the R 2.13.2 software (R Development Core Team 2011) (Online Resources 1,2). The fine sand layers intercalated in the peat profile (likely corresponding to instant aeolian deposits) were not taken into account in the age-depth modelling.
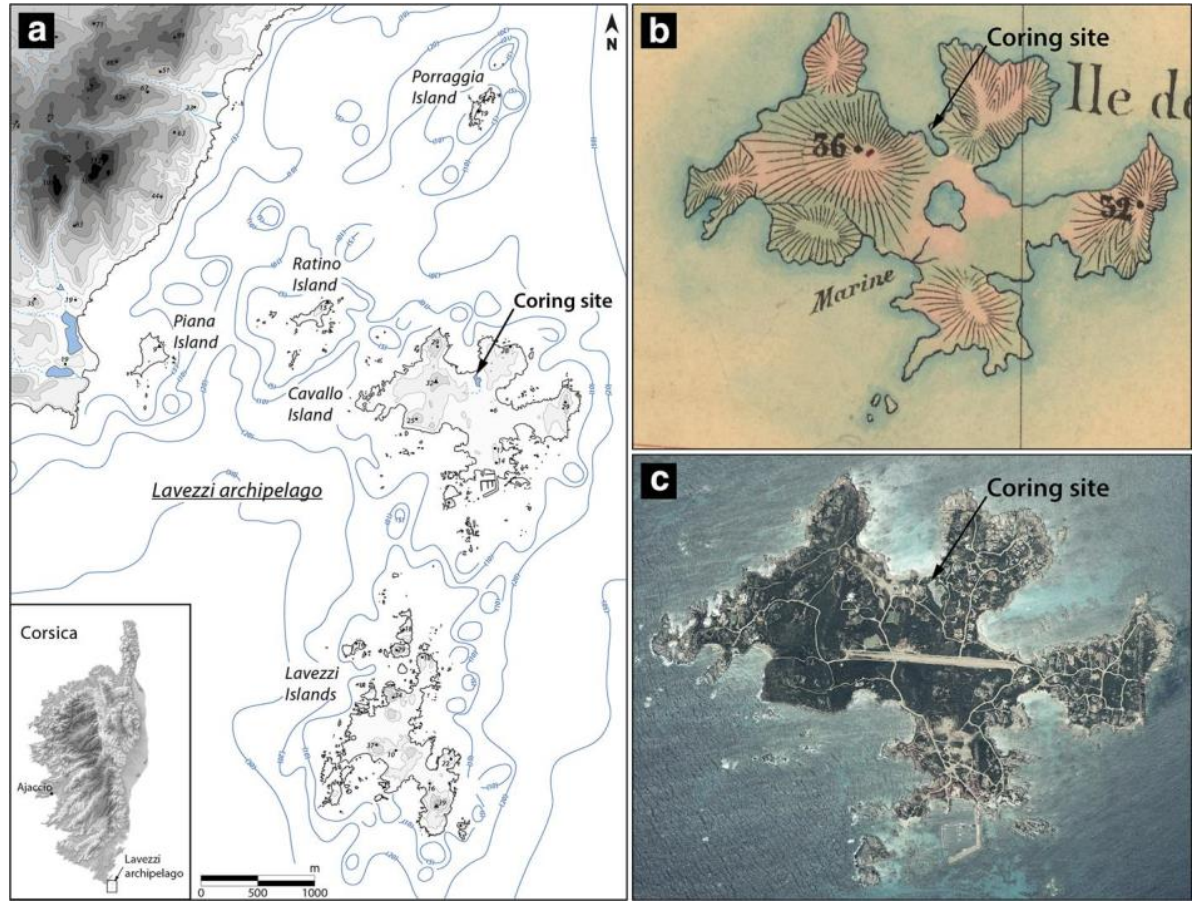

Fig. 1 a Location map of the Lavezzi archipelago (Southern Corsica, France), showing Cavallo Island; b IGN map from 1866 (http://www.geoportail.gouv.fr, SARTENE); c photo of Cavallo Island, taken in 2002 (http://www.geoportail.gouv.fr, aerial photography mission CP02000032_2002_fd2A2B250_0223, picture $\mathrm{n}^{\circ} 223$ ) 


\section{Coleopteran fossil analysis}

Fossil insects were extracted using the standard method (Coope 1986) and Coleoptera remains were identified by direct comparison with modern specimens from a reference collection (see Online Resource 3). The term 'taxa' refers to beetle fossils identified at any taxonomic rank (e.g., species, genus, family). The palaeoecological interpretation of the fossil assemblages is based on the species' modern biological and geographical distribution derived from the literature available for the region (Balachowsky 1949; Caillol 1908; Coiffait 1984; Constantin and Liberti 2011; Delobel and Delobel 2003; Delobel and Tran 1993; Guignot 1947; Hoffman 1950, 1954, 1958; Jeannel 1941, 1942; Koch 1989a, b, 1992; Paulian and Baraud 1982; Saint-Claire Deville 1914; Soldati and Coache 2005; Thérond 1975; Tronquet 2014). These data were compared with the BugsCEP database (Buckland and Buckland 2006) which is a rich source of information on European beetle fauna. The nomenclature and taxonomic order are based on Tronquet (2014).

In order to provide a robust final dataset for supporting interpretations, a method derived from Poirier et al. (2010) was applied to the initial dataset (a 70 samples 9133 beetle taxa matrix, see Online Resource 4). The original method, which was initially used on mollusc death assemblages, was designed to obtain a statistically meaningful dataset of $n$ stations $9 \mathrm{p}$ species using selection criteria. Then the stations were classified into homogeneous groups according to the taxonomic composition of the death assemblages using hierarchical agglomerative cluster analysis. For the present study we employ the same approach and use it to investigate the taxonomic composition and temporal distribution

Table 1 Groups of Coleoptera according to their ecological affinities

Ecological groups $\quad$ Ecological features and non-exhaustive beetle examples

Aquatic Coleoptera

Beetles living in standing and/or running water at some stage of their development (e.g., taxa belonging to the Dytiscidae or Hydrophilidae families) that can be halotolerant or not

Salt marsh/Salt land Coleoptera

Halotolerant aquatic beetles (e.g., Hydrovatus cuspidatus) or nonaquatic beetles living on salty land (e.g., Bledius unicornis)

Woodland and scrubland Coleoptera

Sand dune Coleoptera

Beetles living in forest or shrubby environments (e.g., Scobicia chevrieri, Triodonta cf. cribellata) that can be xylophagous or not

Psammophilous beetles adapted to sand biotope (e.g., Catomus consentaneus, Platytomus laevistriatus)

Driftwood-dependent Coleoptera Beetles strictly associated with driftwood beached along the coastline (e.g., Mesites pallidipennis, Pselactus spadix)

Wetland and waterside Coleopte- Non-aquatic beetles associated with wetlands and marshes (e.g., Dryops, ra

Phalacrus). A few of these beetles were also halotolerant

Open environment Coleoptera

Beetles living in grasslands (e.g., Bruchidius, Longitarsus)

Decayed vegetable matterdependent Coleoptera

Coprophilous/coprophagous Coleoptera

Non-coprophilous beetles feeding or living in decayed vegetal matter (not presented on the Fig. 3a)

Beetles feeding directly upon dung (e.g., Caccobius schreberi, Onthophagus taurus) or predatory, feeding upon small coprophagous organisms such as Diptera larvae (e.g., Oxytelus piceus). A few of these beetles were classed both in this group and that of open environment or woodland and scrubland Coleoptera

No information

In this category are lumped together taxa whose ecology is not sufficiently known and which do not provide any precise ecological information (not presented in Fig. 3a) 
along the profile of Coleoptera fossil assemblages. Thus, samples and taxa that successively match the four following requirements were excluded: (1) taxa identified at family rank, (2), taxa that occurred in less than five samples, (3) taxa for which the sum of relative abundance did not exceed $1 \%$ and (4) samples devoid of fossil beetles. A final dataset of 68 samples $\times 23$ taxa consisting of the most abundant and widely represented beetles and the richest assemblages was obtained. Dissimilarity matrices, as parameterised by BrayCurtis distances, were then compiled for both samples (Samples-matrix) and taxa (Taxamatrix) using the 'rioja' R package (Juggins 2012). A stratigraphically-constrained cluster analysis was carried out on the Samples-matrix via the CONISS agglomeration method (Grimm 1987) to obtain significant insect fauna units (IFUs) and an unconstrained cluster analysis was performed on Taxa-matrix using the UPGMA (Unweighted Pair Group Method Average) method to obtain homogeneous ecological groups. The crosscomparison between the two clusters is given in Fig. 2. Entomological data are expressed in minimal number of individuals (MNI). Fossil beetles have been plotted in a simplified diagram (Fig. 3a, drawn with C2 software; Juggins 2007) according to ecological habitats (Table 1).

The specific richness, i.e., the total number of identified beetle taxa and the Shannon diversity index (Shannon and Weaver 1964) were calculated for each sample. We also calculated the Pielou's evenness index which is sensitive to the relative evenness of taxa in the samples (Pielou 1966). The value is minimal when one taxon dominates the fossil assemblage from one sample and maximal when all the taxa are present in equal abundance within the assemblage.

\section{Pollen and non-pollen palynomorph analyses}

Extraction of pollen fossils and non-pollen palynomorphs (NPP including spores, microforaminiferal linings and algae such as Botryococcus and Spirogyra) from the sediment follows the standard method (Faegri and Iversen 1989). Pollen and NPP counts were performed using a Leica microscope at $\times 500$ magnification oil immersion. Identifications were made with the standard atlases and keys (Beug 2004; Reille 1999; see Online Resource 5). A minimum of 300 pollen grains were counted, beyond this number, only new pollen types were counted. Aquatic and helophytic plants (Alisma, Cyperaceae, Lotus, Myriophyllum type spicatum, Myriophyllum type alterniflorum, Nymphaea, SparganiumTypha type) and NPP were excluded of the total pollen sum. To facilitate the crosscomparison with insect data, some pollen and NPP have been merged into ecological categories (see Online Resource 6) and plotted in Fig. 3a.

\section{Past Relative sea-level framework}

A recent review based on 917 relative sea-level data-points provides a detailed Holocene relative sea-level framework for the western Mediterranean (Vacchi et al. 2016), which made it possible to re-evaluate relative sea-level data published for southeastern France (Laborel et al. 1994; Morhange et al. 2001; Vella and Provansal 2000) and for Corsica (Laborel et al. 1994). These corrected data were plotted on Fig. $3 \mathrm{~b}$ and compared to the predictive model of sea-level on the French Mediterranean coast from Lambeck and Purcell (2005). 


\section{Results}

\section{Lithology}

Sediment profile CAVA-1 is composed of two sedimentary units both interspersed with marine sandy layers (see Online Resource 2). Between 490 and $266 \mathrm{~cm}$, the sediment consists of homogenous fine peat. Fine sandy peat is found deposited between 262 and 160 $\mathrm{cm}$. It must be noted that the curves of total MNI and of Coleoptera specific richness show a similar trend throughout the record (Fig. 3a), which raises the question of preservation and taphonomy. This point will be addressed again later.

\section{Beetle assemblages and diversity}

From a total of 2039 arthropod fossils belonging to 144 taxa, 133 Coleoptera taxa were identified (see Online Resource 4). Thirty-nine percent of them were identified down to the species level, $48 \%$ to the genus and $13 \%$ to a higher taxonomic level. The fossil beetles were dominated by aquatics (35 taxa), by hygrophilous (32 taxa) and then by open envi-ronment and woodland/scrubland-dependent beetles (both 13 taxa). The richness varies from 0 to 29 taxa in all samples (11 taxa in average) and in terms of abundance, each taxa is represented by 1-173 individuals along the sediment core ( 8 individuals on average). Curves of specific richness and of Shannon diversity index have a similar trend since number of taxa and heterogeneity of the diversity are positively correlated $(\mathrm{r}=$ $0.8929 ; \mathrm{P}<0.00001 ; \mathrm{n}=70)$. The Pielou's evenness index suggests that the less diversified samples are also those whose taxa have an equal abundance within the assemblage (Fig. 3a).

The constrained cluster analyses sorted samples into four insect fauna units (Fig. 2). The three basal insect fauna units (IFU_1 to IFU_3) correspond to the lower sedimentary

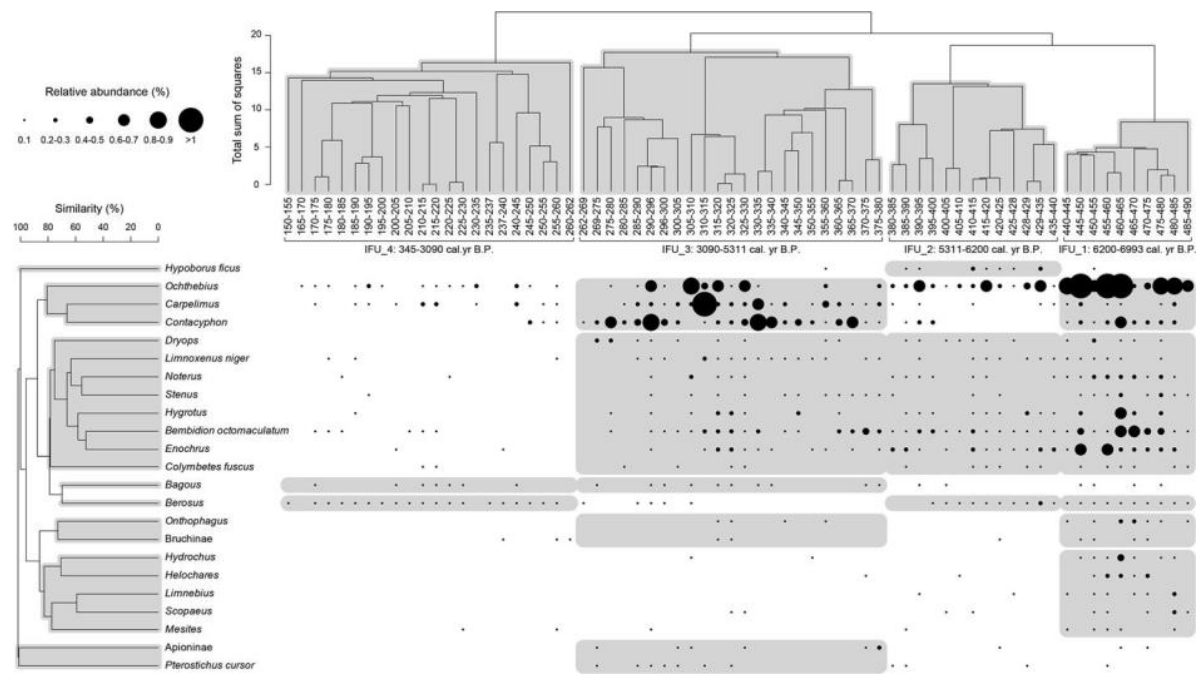

Fig. 2 Constrained hierarchical cluster analysis and unconstrained cluster analysis performed respectively on samples-matrix with the Bray-Curtis distance method and on the Taxa-matrix with the UPGMA aggregation method: grey-shaded areas indicate clusters of beetle groups 
unit (homogenous peat) and IFU 4 corresponds to the upper sedimentary unit (sandy peat). The unconstrained cluster analysis performed on Taxa-matrix allowed us to define eight main beetle assemblages (Fig. 2) detailed in Table 2. The comparison between the two cluster approaches makes it possible to characterise the temporal distribution of each taxa within the eight main beetle assemblages for each IFU. The three aquatic or semi-aquatic taxa of the 'Ochthebius assemblage' are present in each IFU with high relative abundances in IFU_1 and IFU_3. The 'Bembidion octomaculatum assemblage' is the most diversified, since it encompasses three species and species-groups that are found at the water margin (Dryops, Stenus, Bembidion octomaculatum) and five aquatic beetles. All of these taxa are recorded together in IFU_1, IFU_2 and IFU_3 but the relative abundances are generally higher in the first. The two groups of taxa in the 'Onthophagus assemblage' (Onthophagus and Bruchinae) are recorded together only in IFU_1 and IFU_3. The specific composition of the 'Pterostichus cursor assemblage' is the most ecologically incoherent since it combines Apioninae taxa which are commonly found on herbaceous vegetation and $P$. cursor, a halotolerant hygrophilous beetle living on the margins of brackish water. These taxa were sporadically recorded but they were most frequent in IFU_3. The 'Hypoborus ficus, Bagous and Berosus assemblages' comprise a single taxon. Except for $\mathrm{H}$. ficus (which is almost-exclusively recorded in IFU_2), Bagous and Berosus are more or less continuously recorded in every IFU.

\section{History of the coastal wetland inferred from the pollen and beetle fossil assemblages}

A total of 100 plant types belonging to 64 families and 14 NPP were identified via pollen analysis (see Online Resource 5). The most abundant pollen types of aquatic and hygrophilous plants were Sparganium/Typha, Myriophyllum type spicatum, M. type alterniflorum, Radiola linearis type, Isoetes and Cyperaceae. The description and interpretation of the coleopteran, pollen and NPP assemblages, presented in Fig. 3a, are described for each IFU.

Table 2 Coleopteran assemblages obtained by the unconstrained cluster analysis performed on Taxa-matrix (see Fig. 2)

\begin{tabular}{|c|c|}
\hline Coleoptera assemblage & Taxa included and ecological features \\
\hline $\begin{array}{l}\text { Hypoborus ficus } \\
\text { assemblage }\end{array}$ & $\begin{array}{l}\text { Hypoborus ficus (saproxylic beetle digging galleries in the branches of Ficus } \\
\text { carica) }\end{array}$ \\
\hline Ochthebius assemblage & $\begin{array}{l}\text { Ochthebius (aquatic genus where the majority of species are halophilous); } \\
\text { Contacyphon (subaquatic); Carpelimus (wetland margin beetle) }\end{array}$ \\
\hline $\begin{array}{l}\text { Bembidion octomaculatum } \\
\text { assemblage }\end{array}$ & $\begin{array}{l}\text { Dryops; Stenus; Bembidion octomaculatum ( } 3 \text { dump ground beetles); } \\
\text { Limnoxenus niger; Hygrotus; Enochrus ( } 3 \text { aquatic halotolerants); } \\
\text { Colymbetes fuscus; Noterus ( } 2 \text { ubiquitous aquatic beetles) }\end{array}$ \\
\hline Bagous assemblage & Bagous (aquatic beetle of standing or slow-moving waters) \\
\hline Berosus assemblage & Berosus (aquatic beetle of standing waters) \\
\hline Onthophagus assemblage & Onthophagus (coprophilous beetle); Bruchinae (open ground beetle) \\
\hline Hydrochus assemblage & $\begin{array}{l}\text { Hydrochus; Helochares; Limnebius ( } 3 \text { dulcicolous aquatic beetles); Scopaeus } \\
\text { (hygrophilous beetle); Mesites (drift-wood dependent beetle) }\end{array}$ \\
\hline $\begin{array}{l}\text { Pterostichus cursor } \\
\text { assemblage }\end{array}$ & $\begin{array}{l}\text { Apioninae (open-land beetle); Pterostichus cursor (halotolerant hygrophilous } \\
\text { beetle) }\end{array}$ \\
\hline
\end{tabular}


Beetle diversity is maximal (up to 32 taxa per sample). Aquatic and hygrophilous beetles prevail (respectively 27 and 15 taxa) and some taxa of the 'Ochthebius, B. octomaculatum and Hydrochus assemblages' reach their highest relative abundances (Fig. 2). Wetland environment is indicated by freshwater plants (e.g. Myriophyllum type spicatum, Radiola type linoides) and dulcicolous beetles of the 'Hydrochus assemblage' (Figs. 2, 3a) suggesting that no marine influence has significantly disturbed the pond ecosystem during this period although salt marsh and salt land coleopteran are also well-represented in this IFU. These beetles probably indicate the presence of salty environments on Cavallo Island not far from the freshwater pond.

IFU_2(6200-5311 cal. yr B.P.)

During this period, the relative abundances and MNI of aquatic and hygrophilous beetles decrease (respectively 24 and 12 taxa) while diversity remains high. The persistence of wetland taxa of the 'B. octomaculatum assemblage' indicates the persistence of freshwater conditions (Fig. 3a). Aquatic beetle diversity briefly decreases (disappearance and reduction in number of taxa belonging to the 'Hydrochus and Ochthebius assemblages') possibly caused by eutrophication of the pond, as this is suggested by an up to $13 \%$ increase in the salt-intolerant macrophyte Myriophyllum spicatum.

IFU_3(5311-3090 cal. yr B.P)

This unit is marked by an increase in microforaminiferal linings concentrations and regular occurrences of sand dune beetles, suggesting that the mire is subject to an increasing marine influence (Fig. 3a). Beginning around $4400 \mathrm{cal}$. yr B.P., the increase in groups of halotolerant beetles (e.g. Pterostichus cursor and specimens of the genus Ochthebius) and Chenopodiaceae (which probably are halophilous species) also indicates that salinity undoubtedly increased locally (Fig. 3a). Indeed, among the 8 Chenopods currently present on Cavallo Island (Médail et al. 2014), the majority of taxa are halophytes (i.e. Atriplex halimus, Atriplex prostrata, Beta vulgaris subsp. maritime, Halimione portulacoides, Salicornia patula, Salsola kali subsp. tragus), the others being halo-resistant (Chenopodium album) or non-native species recently introduced to the island (Chenopodium ambrosioides). The diversification of wetland beetle fauna (34 taxa) which occurs between 4600 and 4200 cal. yr B.P., simultaneously to the development of Sparganium-Typha (up to 66\%) is followed by a collapse of these wetland beetle fauna (e.g. 'B. octomaculatum assemblage') from 3700 cal. yr B.P. coinciding with the maximal concentration of microforaminiferal linings. During this period, the pond is under a strong marine influence and salt water intrusions are probably occurring.

IFU_4 (3090-345 cal. yr B.P.)

This last unit is marked by the impoverishment of all ecological groups (38 taxa identified in the entire insect fauna unit). From 3100 cal. yr B.P., the increase of Tamarix frequencies (up to 23\%) is concomitant with the decrease of microforaminiferal linings (Fig. 3a), suggesting that the formation of a sand-barrier might have disconnected the pond from marine input. This sand-barrier system (favourable for Tamarix development) probably 
causes a modification of water circulation and creates mixed water sources beginning at 2000 cal. yr B.P., which allows for the persistence of ubiquist (e.g., Berosus, Bagous) or halophilous aquatic beetles of the genus Ochthebius and the development of hygrophilous plants (Cyperaceae). At that time, the morphology of the Greco pond was probably comparable to its current state.

\section{Past changes to the relative sea-level}

Figure $3 b$ is a compilation of data on RSLR available in the literature for the north-west Mediterranean basin and modified according to the last study by Vacchi et al. (2016). First, during the period encompassed by IFU_1, the relative sea-level is estimated as rising from $-6.4 \pm 0.5$ to $-4.7 \pm 0.5$ m.a.s.l. between $\sim 7200$ and 6200 cal. yr B.P. This level is reconstructed at $-2.8 \pm 0.5$ m.a.s.l. at the end of IFU_2 (Vella and Provansal 2000) (Fig. $3 b)$. Whereas the sea-level data for the Rhone Delta show a plateau between $\sim 5000$ and 4000 cal. yr B.P. (Vella and Provansal 2000), data from northern Corsica and La Ciotat indicate respectively a continuous rise until $-1.6 \pm 0.4$ and $-1.3 \pm 0.4$ m.a.s.l. at $\sim 4000$ cal. yr B.P. This suggests a rapid rise of about $5.1 \mathrm{~m}$ during IFU_1, IFU_2 and the first part of IFU_3. Finally, during IFU_4, the sea-level estimated from northern Corsica and southern France coasts indicates a rise of $-1.0 \pm 0.4$ over the last $\sim 3100$ cal. yr B.P. (Laborel et al. 1994; Morhange et al. 2001). The pattern of RSLR indicates a significant decrease in rates of rise for the second part of IFU_3 and all of IFU_4. The last slowing of the marine transgression during IFU_4 is concomitant with the formation of a sand-barrier and the expansion of Tamarix (Figs. 3a, b).

\section{Discussion}

\section{Beetle assemblages as bioindicators of salinity changes}

In reconstructing sea-level variations along coastal marine environments, previous studies have focused on some bioindicator assemblages (e.g., foraminifera, ostracods, diatoms, molluscs). Our results suggest that wetland Coleoptera could represent excellent bioindicators of salinity changes because of their narrow ecological requirements. For example, in the North Sea coastal plain, the increase in number of halotolerant beetles is interpreted as being the result of increasing salinity from marine incursions (Ponel et al. 2007). On Cavallo Island, the record of three dulcicolous aquatic beetles from the 'Hydrochus assemblage' and the presence of salt-intolerant plants (Myriophyllum type spicatum) indicate that freshwater conditions prevailed until $\sim 5500$ cal. yr B.P. Following this, the composition of wetland beetle fauna suggests that until 3700 cal. yr B.P. the salinity rise caused by marine transgression may have resulted in the disappearance of several aquatic beetles (out of 35 fossil aquatic taxa, 94\% of them are present in IFU_1 and IFU_2 and 54\% are in IFU_3), whereas hygrophilous beetles were less impacted (out of a total of 32 hygrophilous beetles, 63\% of them are present in IFU_1 and IFU_2 and 59\% are in IFU_3) (Fig. 3a). Saltmarsh and salt land beetle diversity remains stable but the relative abundance of some halophilous taxa (Pterostichus cursor, Ochthebius) increases until 3700 cal. yr B.P., suggesting that this well-adapted fauna was able to find suitable salinity conditions (Fig. 2). 


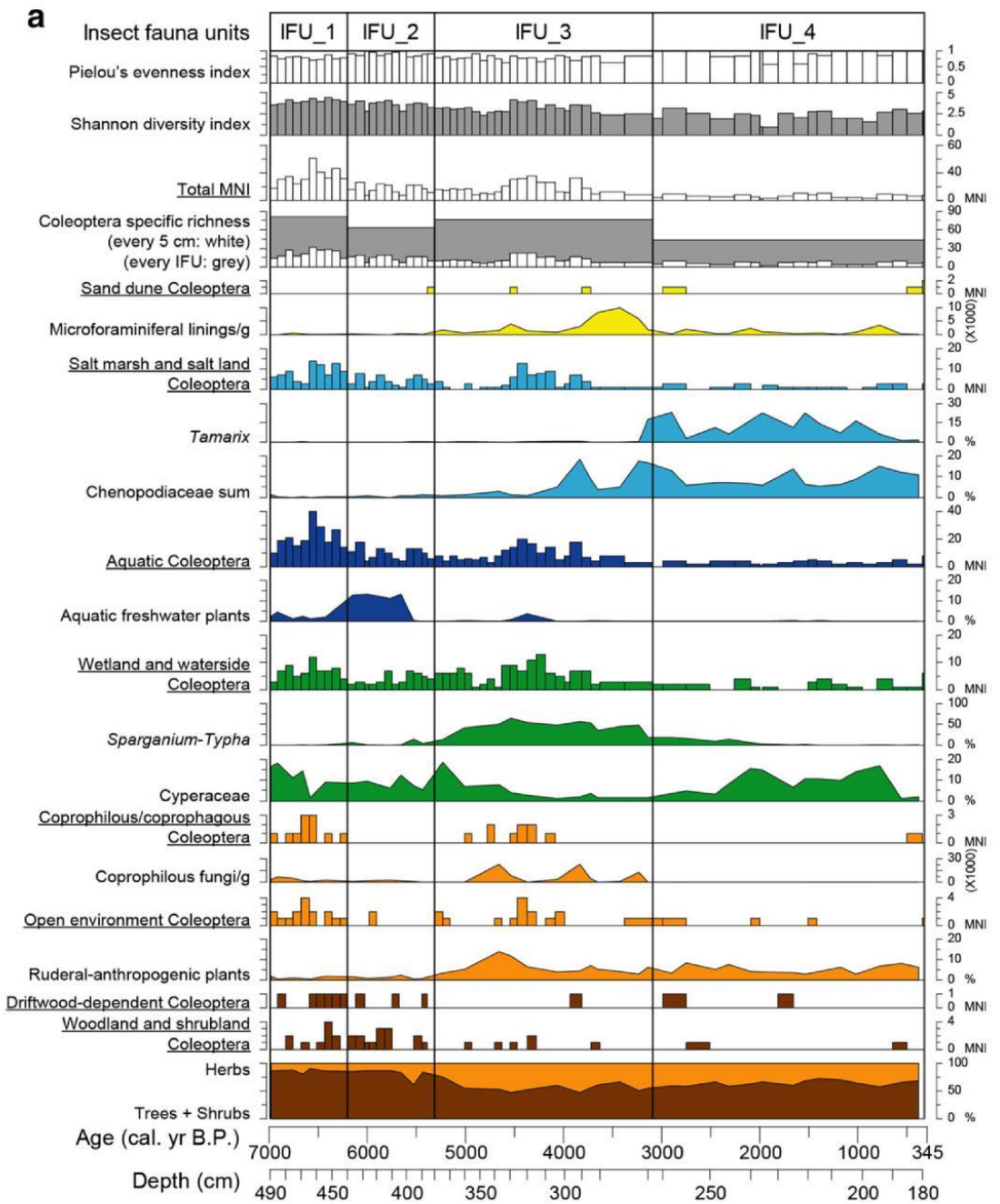

b

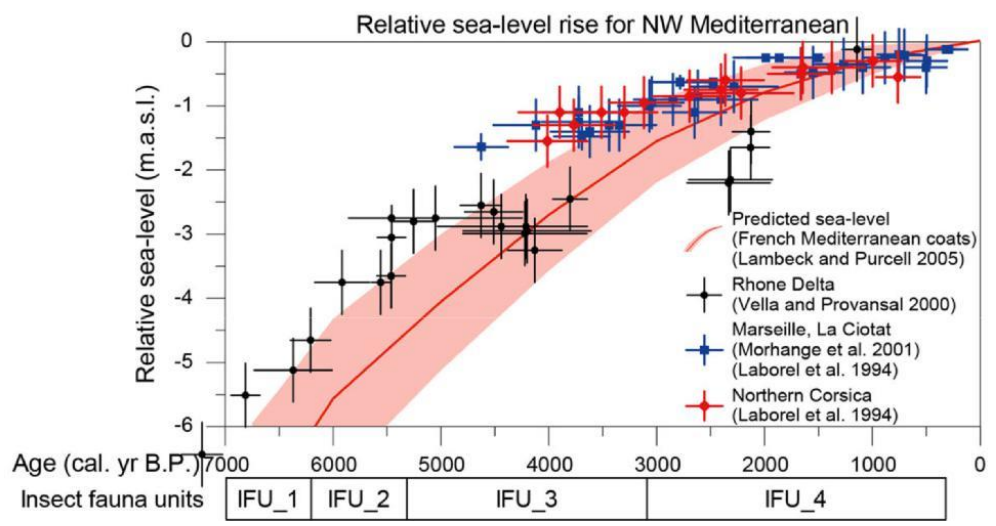


4Fig. 3 a Selected ecological groups of beetles (underlined letters, in minimal number of individuals: MNI), pollen (percentage of the pollen calculation sum) and NPP (concentration of elements by grams) from Greco pond. Taxa included into ecological groups are given in Online Resources 4 and 6. b Relative sealevel curve in the NW Mediterranean Sea from observations in SE France (Laborel et al. 1994; Morhange et al. 2001; Vella and Provansal 2000), Corsica (Laborel et al. 1994) and from eustatic and glacio-hydroisostatic model (Lambeck and Prucell 2005)

\section{The Holocene relative sea-level rise as a driver of coastal wetland biodiversity?}

The succession observed in the beetle assemblages fits well with the reconstruction of past RSLR based on several studies (Fig. 3b): during the period covered by IFU_1 and IFU_2, freshwater indicators are present while the sea-level is remains below $-2.8 \pm 0.5$ m.a.s.l. (Vella and Provansal 2000). When the marine influence is at its maximum in IFU_3, relative sea-level is estimated at $-1.5 \pm 0.3$ m.a.s.l. in southern France (Morhange et al. 2001, corrected by Vacchi et al. 2016) and estimates vary between $-1.3 \pm 0.4$ and $-1.1 \pm 0.4$ m.a.s.l., at respectively $\sim 3800$ and 3500 cal. yr B.P. in northern Corsica (Laborel et al. 1994, corrected by Vacchi et al. 2016) (see Fig. 3b). After 3700 cal. yr B.P., only $31 \%$ of all aquatic taxa, $38 \%$ of all wetland taxa and $58 \%$ of all halotolerant taxa remain. This indicates that the wetland insect richness and abundance decline greatly when freshwater habitats are impacted by a sharp increase in salinity due to a shift of the coastline.

However, the potential impact of taphonomy on the past biodiversity record at Cavallo remains questionable. It must be noted that the drastic lowering of total MNI and Coleoptera specific richness curves is concomitant with sedimentological and fossil evidence of marine influences (Fig. 3a). Therefore, changes from freshwater to brackish water could have impacted the deposition and preservation processes. Moreover, the slight decrease in sedimentation rate from $262 \mathrm{~cm}$ onward might have led to a degradation of beetle macroremains prior to their burial in the sediment (see Online Resource 2). If this hypothesis were valid, all beetle assemblages would have been poorly preserved, which is not the case. As examples, occurrences of Bagous, Berosus or Carpelimus are more-or-less ubiquitous throughout (Fig. 2). There is also a nearly continuous presence of Ochthebius along IFU_4. Moreover, the fossils of this last insect unit do not show the visible marks of degradation commonly found in cases where there are taphonomical problems (i.e., holes, corrosion marks and thinning down of macroremains). Pollen analysis clearly revealed local aquatic vegetation changes and salinity increases in IFU_3 and IFU_4 (Fig. 3a). This rather suggests that the diversity decrease of the Greco pond is a consequence of adverse conditions for fresh water aquatic and hygrophilous beetles.

Schallenberg et al. (2003) also found reduced diversity and altered structure in invertebrate communities in coastal freshwater wetlands following marine intrusions. Other studies at shorter temporal scales generally show an inverse relationship between the increase of salinity and taxa richness of macroinvertebrates in lakes (Hammer 1986), wetlands (Pinder et al. 2005) or rivers (Velasco et al. 2006). Pinder et al. (2005) registered a decline in total wetland species richness as salinity increased (above $4.1 \mathrm{~g}^{-1}$ ) but when salt-tolerant species were excluded, a lower level of salinity (from $2.6 \mathrm{~g} \mathrm{l}^{-1}$ ) led to a decline in species richness. This pattern is comparable to our results, since fresh water beetles of the 'Hydrochus assemblage' first decline in IFU_2 even though the taxa richness remains relatively high until 3700 cal. yr B.P. (Figs. 2 and 3a). 
It must be also noted that another water body was previously located at the center of Cavallo: this swamp has been described in the IGN map dating from 1866 as covering around $1.6 \%$ of the island surface (Fig. 1b). There is no doubt that such a large wetland has played a major role as 'refuge' for aquatic and wetland fauna when environmental conditions became unfavourable in the coastal pond.

\section{Did climate or humans play a role in the observed biodiversity changes?}

The important question remains as to whether other drivers, such as human alteration or climatic changes, in addition to Holocene RSLR have influenced beetle diversity. In the central Mediterranean, high lake levels from Italy (Magny et al. 2009, 2013), low fire activity in the western Mediterranean (Vannière et al. 2011) and pollen-inferred climate reconstructions across the Italian Peninsula (Peyron et al. 2013) suggest a prolonged wet phase from $\sim 4300$ to 3800 cal. yr B.P. However, even though this episode could perhaps explain the transitory diversification of wetland beetles and the scarce presence of aquatic freshwater plants around ca. $4400 \mathrm{cal}$. B.P., climatic factors apparently played a minor role. Notwithstanding the salinisation process from $\sim 4100$ cal. yr B.P. which could have possibly been buffered by wetter conditions, the impoverishment of the wetland beetle fauna after 3700 cal. yr B.P. seems mainly due to the RSLR because respectively 69 and $63 \%$ of aquatic and hygrophilous fossil beetles are only recorded at times prior to marine intrusions.

On the other hand, it is well known that human activities exacerbated by sea-level changes have triggered coastal instability (Anthony et al. 2014). In the Mediterranean region, human impacts led to major environmental changes that are reflected in the coleopteran fauna dating back to Neolithic times (Andrieu-Ponel and Ponel 1999) and during the Antiquity (Andrieu-Ponel et al. 2000). On Cavallo Island, significant records of open environment and coprophilous beetles, ruderal-anthropogenic plants and coprophilous fungi suggest successive phases of human activities during the Neolithic period (from 6993 to 6200 cal. yr B.P.), the Chalcolithic period (from 5000 to 4000 cal. yr B.P.) and since the Iron Age (from 2700 cal. yr B.P. onward). This is confirmed by several traces of human occupation in the Lavezzi archipelago since the Chalcolithic time according to Agostini (1978). The opening of the vegetation (increase of herbaceous pollen) and the decline of saproxylic beetles which are clearly recorded during the second anthropogenic phase from 5000 to 4000 cal. yr B.P. suggest that this long-time human occupation has impacted the landscape. Nevertheless, our results suggest that there is no negative impact on wetland and aquatic Coleoptera, since a marked abundance increase in these communities is recorded around ca. 4400 cal. B.P. (Fig. 3a). It is likely that the decline in trees and shrubs induced by humans should have caused an increase in soil erosion and the progressive filling in of the pond, leading to the reed bed (Sparganium-Typha) expansion on the pond margin along with the associated hygrophilous beetle fauna. Finally, the most 'deleterious' human impact has certainly been the recent urbanisation of Cavallo since the 1970s (see Fig. 1c). The filling in of the main swamp during the construction of an airstrip is probably partially involved in the differences between current and past biodiversity, but deconstructing its specific impact is beyond the scope of this paper. Moreover, this urbanisation predated all modern entomological inventories (Cocquempot and Rungs, 2009; Médail et al. 2014, 2015). 


\section{Past local extinction of some remarkable beetles}

Currently 283 beetles species are known to inhabit the Lavezzi archipelago (Cocquempot and Rungs 2009; Médail et al. 2014, 2015). The comparison of palaeoecological data and modern inventories shows that 63 of them were found in the fossil assemblages whereas 1 family, 1 subfamily, 31 genera and 37 species of fossil beetles were not reported. Although this result could be tempered by the fact that the modern Coleoptera fauna of Cavallo is probably incompletely inventoried, $60 \%$ of the hitherto unknown taxa are aquatic and hygrophilous beetles (respectively 24 and 18 taxa on a total of 70). Both are relatively easy to detect, since the Greco pond is the only extant body of water on the island. This suggests that many beetles became locally extinct during a short time span (less than 7000 years).

Even though RSLR has directly affected the aquatic and hygrophilous coleopteran diversity through a major change in salinity, it has also induced an indirect impoverishment of beetle fauna through the wetland vegetation composition changes. Indeed, many authors have shown a close relationship between macrophytes communities and the diversity, abundance and distribution patterns of invertebrates (Ali et al. 2007; Walker et al. 2013) since they play a major role in maintaining the freshwater ecosystems by determining the physical structure of these systems (Chambers et al. 2008), by increasing habitat complexity (Thomaz and Ribiero da Cunha 2010), and by constituting a food resource for invertebrate populations (Habid and Yousuf 2015). Thus, the disappearance of salt-intolerant plants (i.e. Alisma-type, Lythrum type junceum, L. type salicaria, Myriophyllum type spicatum, Radiola linearis-type) has been tantamount to a loss of habitat for stenotopic species (Fig. 3a). Such is the case of Hylobius transversovittatus and Phytobius leucogaster which respectively live on Lythrum salicaria and Myriophyllum sp. (Koch 1992) that were only observed between 6500 and 4500 cal. yr B.P.

The Holocene RSLR cannot by itself obviously explain the apparent extinction of hygrophilous taxa of the reed bed such as Protapalochrus flavolimbatus and Oodes gracilis (Koch 1989a; Saint Claire Deville 1914) since their habitat is still present on the Greco pond. The recent human impact on the Island, which has caused particular damage to Cavallo's central swamp, has undoubtedly played a major role in the local extinction of these stenotopic species. As already evidenced in southern France, drainage and expansion of cultivation might have contributed to regional extinction of Odacantha melanura and Cerapheles lateplagiatus, two species that occur in very similar biotopes (Andrieu-Ponel and Ponel 1999). As a whole, the fossil occurrences of all these now-absent wetland species suggest that their past regional distributions were greater than they are today, as is true of their biotopes.

\section{Conclusion}

Our multidisciplinary investigation has revealed that the past ecosystem dynamics and biodiversity changes in the coastal wetland of Cavallo Island were significantly driven by 7000 years of RSLR. Coleoptera fossil assemblages responded rapidly to increasing salinity, culminating in the local extinction of freshwater aquatic beetles and the regression of hygrophilous and riparian freshwater beetles. The regression/disappearance of fresh-water helophytes and the subsequent increase in salty ground plants have played also a major role in these insect diversity changes. Furthermore, the recent destruction of the central swamp on Cavallo, which may have played a role as a reservoir for the freshwater 
insect community, has undoubtedly worsened the resilience of the island ecosystems that have faced past RSLR.

It can therefore be concluded that the effects of ongoing RLSR on coastal diversity could be more severe in areas destabilised by humans: because the Mediterranean coastline is experiencing increasing human pressure on natural habitats (due to urbanisation, tourism, concretisation of the littoral; see Beltrame et al. 2012), the protection of coastal freshwater bodies and inland marshes (especially on small continental islands; see Médail 2013; PIM initiative: Initiative pour les petites îles de Méditerranée) represents a high priority. Such a habitat loss has already resulted in a drastic retraction of the geographical range of many aquatic beetles over the past hundred years (Ribera 2000). Thus, a Mediterranean sea-level rise of 9.8-25.6 cm by 2050, as estimated by Galassi and Spada (2014), represents an added threat on top of generalised direct human pressure: coastal freshwater wetlands will probably suffer salinity increases while inland water bodies, which for now are distant from the coastline, will no longer play the role of refugia.

Facing future RLSR, comparison between prospective studies such as Irmler et al. (2002) and retrospective studies such as the present work will be valuable in improving estimates of how coastal wetland insect diversity will be likely to change their composition and adapt. This is going to be an important field of research in the Mediterranean basin where some 12,500 islands of all sizes have been identified, most of them biodiversity hotspots (Médail and Myers 2004; Médail 2013). The future trajectories of these island ecosystems remain questionable, but there is no doubt that their capability to be resilient to RSLR depends on the persistence of natural habitats beyond the coastline. The major challenge for decision-makers will be to preserve and protect these future refugia (for instance, by reducing damming, draining, fragmentation, pollution and isolation of source habitats).

Acknowledgements This study was incorporated within the framework of the $\mathrm{CoP}^{2} \mathrm{~A}$ (Corsican Palaeoclimate, Palaeoenvironments \& Anthropization) project, which is supported by the Laboratoire d'Excellence Objectif-Terre Bassin méditerranéen (Labex OT-Med) of Aix Marseille University (ANR-11LABEX-0061), and by the DyPaCo (Dynamique des paléoenvironnements de la Corse, convention no.15/005) project which is supported by the Office de l'environnement de la Corse (OEC)/Conservatoire botanique national de Corse. The fieldwork was funded by the French government (projet Investissements d'Avenir) within the Initiative d'excellence A*MIDEX/MEDNET of Aix Marseille University (ANR-11IDEX-0001-02), and performed during a field school of the Master SET-SBEM of Aix Marseille University. The authors wish to thank the Conservatoire Botanique National de Corse and its director Laetitia Hugot for their constant support of this research. We also thank the Association pour la protection de l'environnement de l'île de Cavallo (APEIC), notably Mrs. Matthieu Bidali and Michel Orlanducci for their permission to work on the private island of Cavallo. Finally, thanks are due to the two anonymous reviewers for their constructive remarks.

\section{References}

Agostini P (1978) Recherches archéologiques dans l'île Cavallu (Bonifacio, Corse) 1972-1977. Archeol Corsa 3:15-54

Ali MM, Mageed AA, Heikal M (2007) Importance of aquatic macrophyte for invertebrate diversity in large subtropical reservoir. Limnollogica 37:155-169. doi:10.1016/j.limno.2006.12.001

Anderson NJ, Bugmann H, Dearing JA, Gaillard MJ (2006) Linking palaeoenvironmental data and models to understand the past and to predict the future. Trends Ecol Evol 21:696-704. doi:10.1016/j.tree.2006. 09.005

Andrieu-Ponel V, Ponel P (1999) Human impact on Mediterranean wetland Coleoptera: an historical perspective at Tourves (Var, France). Biodiv Conserv 8:391-407 
Andrieu-Ponel V, Ponel P, Bruneton H, Leveau P, de Beaulieu JL (2000) Palaeoenvironments and cultural landscapes of the last 2000 years reconstructed from pollen and Coleopteran records in the Lower Rhône Valley, southern France. The Holocene 10:341-355

Anthony EJ, Marriner N, Morhange C (2014) Human influence and the changing geomorphology of Mediterranean deltas and coasts over the last 6000 years: from progradation to destruction phase? Earth-Sci Rev 139:336-361. doi:10.1016/j.earscirev.2014.10.003

Balachowsky AS (1949) Faune de France 50. Coléoptères Scolitydae. Libr. Fac. Sci, Paris

Bellard C, Leclerc C, Courchamps F (2013a) Impact of sea level rise on the 10 insular biodiversity hotspots. Glob Ecol Biogeogr 23:203-212. doi:10.1111/geb.12093

Bellard C, Leclerc C, Courchamps F (2013b) Potential impact of sea level rise on the French islands worldwide. Nat Conserv 5:75-86. doi:10.3897/natureconservation.5.5533

Beltrame C, Chazée L, Galewski T, Perennou C (2012) Mediterranean wetlands: outlook. First Mediterranean wetlands observatory report-Technical report-2012. Tour du Valat, France

Beug HJ (2004) Leitfaden der Pollenbestimmung für Mitteleuropa und angrenzende Gebiete. Verlag Friedrich Pfeil, Munich

Blaauw M (2010) Methods and code for 'classical' age-modelling of radiocarbon sequences. Quat Geochronol 5:512-518. doi:10.1016/j.quageo.2010.01.002

Buckland PI, Buckland PC (2006) BugsCEP Coleopteran ecology package. IGBP PAGES/World Data Center for Paleoclimatology Data Contribution Series \# 2006-116. NOAA/NCDC Paleoclimatology Program, Boulder CO, USA. URL: http://www.bugscep.com

Caillol H (1908) Catalogue des Coléoptères de Provence d'après des documents recueillis et groupés, 1er partie. Société des Sciences Naturelles de Provence, Marseille

Chambers PA, Lacoul P, Murphy KJ, Thomaz SM (2008) Global diversity of aquatic macrophytes in freshwater. Hydrobiologia 595:9-26. doi:10.1007/s10750-007-9154-6

Cocquempot C, Rungs C (2009) Liste des Arthropodes terrestres recensés dans les réserves naturelles des îles Cerbicale et Lavezzi (France, Corse-du-Sud). Biocosme Mésogéen 26:1-56

Coiffait H (1984) Coléoptères Staphylinides de la région paléartique occidentale, V, Sous famille Paederinae, Tribu Paederini 2, Sous famille Euaesthetinae. Nouv Rev Entomol Suppl 13:1-424

Constantin R, Liberti G (2011) Coléoptères Dasytidae de France. Société linnéenne de Lyon, Lyon Coope GR (1986) Coleoptera analysis. In: Berglund BE (ed) Handbook of holocene palaeoecology and palaeohydrology. Wiley, Chichester, pp 703-713

Coord Tronquet M (2014) Catalogue des Coléoptères de France. Association Roussillonnaise d'Entomologie, Perpignan

Courchamp F, Hoffman BD, Russell JC, Leclerc C, Bellard C (2014) Climate change, sea-level rise, and conservation: keeping island biodiversity afloat. Trends Ecol Evol 29:127-130. doi:10.1016/j.tree. 2014.01.001

Delobel A, Delobel B (2003) Les plantes hôtes des bruches (Coleoptera Bruchidae) de la faune de France, une analyse critique. Bull mens Soc Linn Lyon 72:199-221

Delobel A, Tran M (1993) Les Coléoptères des denrées alimentaires entreposées dans les régions chaudes, Faune tropicale 32. CTA/Orstom Editions, Paris

Faegri K, Iversen J (1989) Textbook of pollen analysis, 4th edn. Wiley, New York

Galassi G, Spada G (2014) Sea-level rise in the Mediterranean Sea by 2050: roles of terrestrial ice melt, steric effects and glacial isostatic adjustment. Glob Planet Change 123:55-66. doi:10.1016/j.gloplacha. 2014.10.007

Grimm EC (1987) CONISS: a fortran 77 program for stratigraphically constrained cluster analysis by the method of incremental sum of squares. Computer Geosci 13:13-35

Guignot F (1947) Coléoptères Hydrocanthares, Faune de France 48. Paul Lechevalier, Paris

Habid S, Yousuf A (2015) Effect of macrophytes on Phytophilous macroinvertebrate community: a review. J Entomol Zool Stud 3:377-384

Hammer UT (1986) Saline Lake Ecosystems of the World. Junk W Publishers, Dordrecht

Hoffman A (1950) Coléoptères Curculionides (première partie). Faune de France, vol 52. Librairie de la Faculté des Sciences, Paris

Hoffman A (1954) Coléoptères Curculionides (deuxième partie). Faune de France, vol 59. Fédération Franc, aise des Sociétés de Sciences Naturelles, Paris

Hoffman A (1958) Coléoptères Curculionides (troisième partie). Faune de France, vol 62. Fédération Franc, aise des Sociétés de Sciences Naturelles, Paris

Irmler U, Heller K, Meyer H, Reinke HD (2002) Zonation of ground beetles (Coleoptera: Carabidae) and spiders (Araneida) in salt marshes at the north and the Baltic sea and the impact of the predicted sea level increase. Biodiv Conserv 11:1129-1147 
Jeannel R (1941) Coléoptères Carabiques première partie, Faune de France 39. Paul Lechevalier et Fils, Paris

Jeannel R (1942) Coléoptères Carabiques deuxième partie, Faune de France 40. Paul Lechevalier et Fils, Paris

Juggins S (2007) C2 Version 1.5 user guide. Software for ecological and palaeoecological data analysis and visualisation. Newcastle University Press, Newcastle upon Tyne

Juggins S (2012) The rioja package: Analysis of Quaternary Science Data, R package, version 0.7-3. http:// cran.r-project.org/package=rioja

Koch K (1989a) Die Käfer Mitteleuropas, Ökologie 1. Goecke and Evers, Krefeld

Koch K (1989b) Die Käfer Mitteleuropas, Ökologie 2. Goecke and Evers, Krefeld

Koch K (1992) Die Käfer Mitteleuropas, Ökologie 3. Goecke and Evers, Krefeld

Laborel J, Morhange C, Lafont R, Le Campion J, Laborel-Deguen F, Sartoretto S (1994) Biological evidence of sea-level rise during the last 4500 years on the rocky coasts of continental southwestern France and Corsica. Mar Geol 120:203-223. doi:10.1016/0025-3227(94)90059-0

Lambeck K, Purcell A (2005) Sea-level change in the Mediterranean sea since the LGM: model predictions for tectonically stable areas. Quat Sci Rev 24:1969-1988. doi:10.1016/j.quascirev.2004.06.025

Magny M, Vannière B, Zanchetta G, Fouache E, Touchais G, Petrika L, Coussot C, Walter-Simonnet AV, Arnaud F (2009) Possible complexity of the climatic event around 4300-3800 cal. BP in the central and western Mediterranean. The Holocene 19:823-833. doi:10.1177/0959683609337360

Magny M, Combourieu-Nebout N, de Beaulieu JL et al (2013) North-south palaeohydrological contrasts in the central Mediterranean during the Holocene: tentative synthesis and working hypotheses. Clim Past 9:2043-2071. doi:10.5194/cp-9-2043-2013

Magurran AE, Baillie SR, Buckland ST, Dick JM, Elston DA, Marian Scott E, Smith RI, Somerfield PJ, Watt AD (2010) Long-term datasets in biodiversity research and monitoring: assessing change in ecological communities through time. Trends Ecol Evol 25:574-582. doi:10.1016/j.tree.2010.06.016

Médail F (2013) The unique nature of Mediterranean island floras and the future of plant conservation. In: Cardona Pons E, Estaún Clarisó I, Comas Casademont M, Fraga i Arguimbau P (eds) Islands and plants: preservation and understanding of flora on Mediterranean islands. 2nd Botanical Conference in Menorca. Consell Insular de Menorca, Institut Menorqui' d'Estudis, Recerca 20, Menorca, pp 325350

Médail F, Ponel P, Brousset L, Poher Y, Master SET SBEM students (Aix Marseille University) (2014). Contributions à l'inventaire de la biodiversité terrestre de l'île de Cavallo (Archipel Lavezzi, Bonifacio, Corse du Sud). Note naturaliste, Initiative pour les Petites Îles de Méditerranée (PIM). www. initiative-pim.org/document/55542

Médail F, Ponel P, Rivière V, Master SET SBEM students (Aix Marseille University) (2015). Contributions à l'inventaire des arthropodes terrestres et aquatiques sur l'île de Cavallo (Archipel Lavezzi, Bonifacio, Corse du Sud). Note naturaliste, Initiative pour les Petites Îles de Méditerranée (PIM). www.initiative-pim.org/document/79864

Médail F, Myers N (2004) Mediterranean Basin. In: Mittermeier RA, Robles Gil P, Hoffmann M, Pilgrim J, Brooks T, Mittermeier CG, Lamoreux J, da Fonseca GAB (eds) Hotspots revisited: earth's biologically richest and most endangered terrestrial eco regions. CEMEX, Monterrey, Conservation International, Washington, pp 144-147

Morhange C, Laborel J, Hesnard A (2001) Changes of relative sea level during the past 5000 years in the ancient harbor of Marseilles, Southern France. Palaeogeogr Palaeoclimatol Palaeoecol 166:319-329

Nicholls RJ, Woodroffe C, Burkett V (2016) Coastal degradation as an indicator of global change. In: Letcher T (ed) Climate change: observed impacts on planet earth, 2nd edn. Elsevier Press, Oxford, pp 309-324

Paulian R, Baraud J (1982) In: Lechevalier S.A.R.L (ed) Faune des Coléoptères de France, vol 2. Lucanoidea et Scarabaeoidae. Encyclopédie Entomologique 43 Paris

Peyron O, Magny M, Goring S et al (2013) Contrasting patterns of climatic changes during the Holocene across the Italian Peninsula reconstructed from pollen data. Clim Past 9:1233-1252. doi:10.5194/cp-91233-2013

Pielou E (1966) The measurement of diversity in different types of biological collections. J Theor Biol 13:131-144

Pinder AM, Halse SA, McRae JM, Shiel RJ (2005) Occurrence of aquatic invertebrates of the wheat belt region of western Australia in relation to salinity. Hydrobiologia 543:1-24. doi:10.1007/s10750-0045712-3

PIM initiative: Initiative pour les petites îles de Méditerranée. www.initiative-pim.org

Poirier C, Sauriau PG, Chaumillon E, Bertin X (2010) Influence of hydro-sedimentary factors on mollusc death assemblages in a temperate mixed tide-and-wave dominated coastal environment: implications for the fossil record. Cont Shelf Res 30:1876-1890. doi:10.1016/j.csr.2010.08.015 
Ponel P, Gandouin E, Coope GR, Andrieu-Ponel V, Guiter F, Van Vliet-Lanoë B, Franquet E, Brocandel M, Brulhet J (2007) Insect evidence for environmental and climate changes from Younger Dryas to Sub-Boreal in a river floodplain at St-Momelin (St-Omer basin, northern France), Coleoptera and Trichoptera. Palaeogeogr Palaeoclimatol Palaeoecol 245:483-504. doi:10.1016/j.palaeo.2006.09.005

R Development Core Team R (2011) R: a language and environment for statistical computing. R foundation for statistical computing, Vienna. http://www.R-project.org

Reille M (1984) Origine de la végétation actuelle de la Corse sud-orientale; analyse pollinique de cinq marais côtiers. Pollen Spores 26:43-60

Reille M (1992) New pollen-analytical researches in Corsica: the problem of Quercus ilex L. and Erica arborea L., the origin of Pinus halepensis Miller forests. New Phytol 122:359-378

Reille M (1999) Pollen et spores d'Europe et d'Afrique du Nord, 2nd edn. Laboratoire de Botanique Historique et Palynologie, Marseille

Ribera I (2000) Biogeography and conservation of Iberian water beetles. Biol Conserv 92:131-150 Saint-

Claire Deville J (1914) Catalogue critique des coléoptères de la Corse. Imprimerie Adeline, Poisson G et $\mathrm{Cie}$, Caen

Schallenberg M, Hall CJ, Burns CW (2003) Consequences of climate-induced salinity increases on zooplankton abundance and diversity in coastal lakes. Mar Ecol Prog Ser 251:181-189

Shannon CE, Weaver W (1964) The mathematical theory of communication. University of Illinois Press, Urbana

Soldati F, Coache A (2005) Faunistique des Coléoptères Tenebrionidae de Corse, résultats d'une deuxième champagne de prospections. Bull Soc Linn Bordeaux 33:79-98

Thérond J (1975-1976) Catalogue des Coléoptères de la Camargue et du Gard I, II. Société d'Etude des Sciences Naturelles de Nîmes, Nîmes

Thomaz SM, Ribiero da Cunha E (2010) The role of macrophytes in habitat structuring in aquatic ecosystems: methods of measurement, causes and consequences on animal assemblages' composition and biodiversity. Acta Limnol Bras 22:218-236. doi:10.4322/actalb.02202011

Vacchi M, Marriner N, Morhange C, Spada G, Fontana A, Rovere A (2016) Multiproxy assessment of Holocene relative sea-level changes in the western Mediterranean: sea-level variability and improvements in the definition of the isostatic signal. Earth-Sci Rev 155:172-197. doi:10.1016/j. earscirev.2016.02.002

Vannière B, Power MJ, Roberts N et al (2011) Circum-Mediterranean fire activity and climate changes during the mid-Holocene environmental transition (8500-2500 cal. BP). The Holocene 21:53-75. doi:10.1177/0959683610384164

Velasco J, Millán A, Hernández J, Gutiérrez C, Abellán P, Sánchez D, Ruiz M (2006) Response of biotic communities to salinity changes in a Mediterranean hypersaline stream. Saline Syst 2:12. doi:10.1186/ 1746-1448-2-12

Vella C, Provansal M (2000) Relative sea-level rise and neotectonic events during the last $6500 \mathrm{yr}$ on the southern eastern Rhône delta, France. Mar Geol 170:27-39

Virah-Sawmy M, Willis KJ, Gillson L (2009) Threshold response of Madagascar's littoral forest to sealevel rise. Global Ecol Biogeogr 18:98-110. doi:10.1111/j.1466-8238.2008.00429.x

Walker PD, Wijnhoven S, van der Velde G (2013) Macrophyte presence and growth form influence macro invertebrate community structure. Aquat Bot 104:80-87. doi:10.1016/j.aquabot.2012.09.003

Willis KJ, Bailey RM, Bhagwat SA, Birks HJB (2010) Biodiversity baselines, thresholds and resilience: testing predictions and assumptions using palaeoecological data. Trends Ecol Evol 25:583-591. doi:10. 1016/j.tree.2010.07.006

Wong PP, Losada IJ, Gattuso JP, Hinkel J, Khattabi A, McInnes KL, Saito Y, Sallenger A (2014) Coastal systems and low-lying areas. In: Field CB, Barros VR, Dokken DJ, Mach KJ, Mastrandrea MD, Bilir TE, Chatterjee M, Ebi KL, Estrada YO, Genova RC, Girma B, Kissel ES, Levy ES, MacCraken S, Mastrandrea PR, White LL (eds) Climate change 2014: impacts, adaptation and vulnerability. Part A: global and sectoral aspects. contribution of working group II to the Fifth assessment report of the intergovernmental panel on climate change. Cambridge University Press, Cambridge

Woodroffe CD, Murray-Wallace CV (2012) Sea-level rise and coastal change: the past as a guide to the future. Quat Sci Rev 54:4-11. doi:10.1016/j.quascirev.2012.05.009 